\title{
高架橋上の人工地盤緑化地における底面貯水層の効果
}

\section{The Effect of a Rain Water Store under the Layer of Fill-up Soil on the Overhead Line}

\author{
山田宏之* 赤松 潤** 養父志乃夫***
}

Hiroyuki YAMADA Jun AKAMATSU Shinobu YABU

\begin{abstract}
摘要 : 奈良県大和高田市の高架橋上に造成した人工地盤緑化試験区において，雨水の底面貯水層の効 果の検証を行った。植栽後約 1 年目の地被類亡低木類の枯死率と被覆面積を土壌種類の違い, 貯水層 の有無, 貯水層への通気の有無で比較した結果, 人工土壤の使用は生育量を增大させる場合が多いも のの，枯死率の增大など逆の効果もあり，一概に優れているとは言えないこと，底面貯水は枯死率を 引き下げるには有効だか，生育量の增大には寄与しない場合もあること，底面貯水層への通気の効果 はほとんど認められないことなどが把握された。貯水層の効果は，土壤種，植栽植物種の違いにより 様々であり，ときには全く逆の結果をもたらすこともあることが分かった。
\end{abstract}

\section{1.はじめに}

人工地盤の緑化を行う場合，一般に植栽基盤厚が十分に厚けれ ば雨水のみで植物の生育が維持できるとされるが3(34), 基盤厚の増 加に比例して荷重も増加する。建築物と比較すると, 土木構造物 の積載荷重の上限は高いのが普通であるが, それでも道路高架橋 等においては積載荷重の余裕はさほど大きくない。人工軽量土壌 を用いれば，ある程度の土壌厚を確保することは可能であるが， 道路高架のような広大な面積を全て人工軽量土壌で基盤造成する というのは，コストの点から見て難しい(9)。

このため, 道路高架橋緑化の場合においても建築物之同様, 荷 重低減のための工夫が求められることになる。建築物の屋上のよ うな場所では，上水道を使った灌水装置を併用した薄層，軽量の 植栽基盤が実用に供されているが(10)，一般に道路高架上では，こ ういった給水施設は皆無である。給水車を用いて灌水するとして も, 操車スペースが極端に限定された高架橋上では困難なことが 容易に予想される。

無灌水あるいは低頻度灌水を目標とした工夫の一つに，基盤底 部に雨水の貯留層を設けるシステムがあげられる。プランター等 の気滵性の高い容器では, しばしば用いられる方法であり ${ }^{6)}$, 実 用新案も取得されている（実用新案登録第 1844863 号，第 194407 号等)。また, 底面灌水法については, 花卉栽培などでは 普通に行われている方法であり, 研究事例む数多く発表されてい $3^{577 ?}$ 。しかしながら, 高架橋上といった大規模な造園工事に際し て底面眝水方式が用いられたという事例は少ないうえに，追跡調 査結果等もほとんど発表されていない。

こうした現状から，人工地盤上で無灌水管理を実現させるため の基盤造成技術上の基礎的なデータとして，今回，雨水の底面貯
水層を有する区と対照区を有する試験植栽地を対象とした調査の 解析結果をまとめたので報告する。

\section{2. 植栽試験区の概要}

試験区は奈良県大和高田市の国道の高架橋上に設定した。1996 年 3 月に造成・植栽したもので，緑化面積は約 $1650 \mathrm{~m}^{2}$ である。 試験区は大きく2つに分けられ，現地産マサ土に体積比で $50 \%$ のパーライトを混合した改良土壌と, 屋上緑化等で使用実績の多 い人工軽量土壌 A（真珠岩パーライト, 鉱物䋐維, 珪藻士焼成粒, 肥料の混合物）の 2 種の基盤材を用いた対比試験区となってい

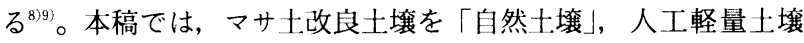
Aを「人士土壤」と記す。造成時の土壤分析結果のうち, 肥料分 の測定結果を表一 1 に示す。

今回測定対象とした試験区は全 19 区のうちの 8 区であり，上 壤層の厚みは地被区で $30 \mathrm{~cm}$ （路盤傾斜により一部 $15 \mathrm{~cm}$ 程度）, 低 木区で $30 \mathrm{~cm}$ (人工䁃) と $45 \mathrm{~cm}$ (自然土壌) である。一部の区 画には土嚊層の下に雨水貯留層を，更にそのうちの一部の区には 貯水層に至る通気管を設置している。調査は，これら貯水構造の 異なる 3 種の試験区について実施した。各々の基盤の構造概念図 は図ー 1 のようである。排水層及び眝水層はパーライト（4２5 mm）によって構成されており，土壌層とは不織布で遮断されてい る。排水口の位置により，このパーライト層が，排水層または貯 水層として機能するようになる。眝水構造の区には，水の吸い上 げを促進する目的で, 化学䋐維を直径 $10 \mathrm{~mm}$ 程度に束ねた吸上管 を土壌層から貫入させている。このような排水構造と道路の排水 勾配が全面に設けられているために，土壌層の排水性は極めて良 好に保たれている。
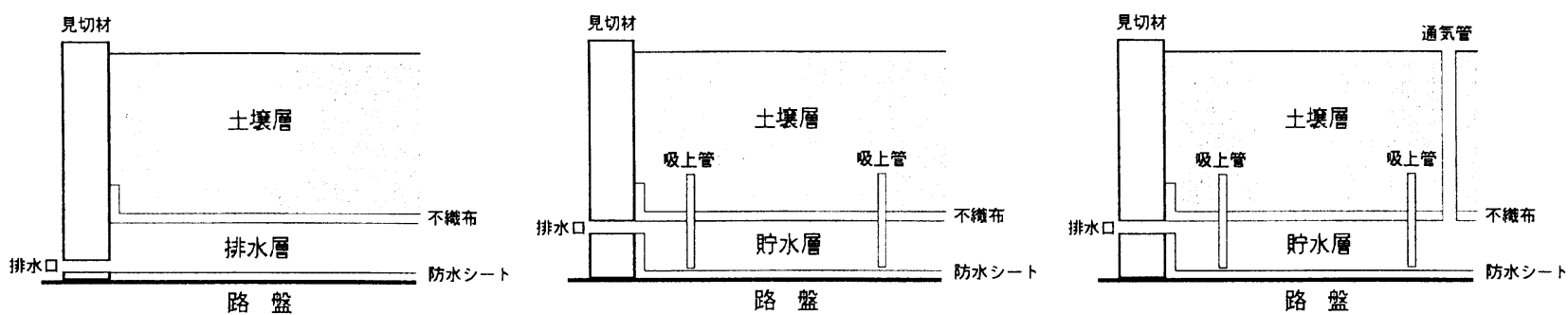

図-1 基盤の構造概念図（左: 無貯水区 中: 貯水区 右: 貯水・通気区）

•(財都市緑化技術開発機構 “住宅・都市整備公団 ***和歌山大学システム工学部 
植栽植物種は地被類から中高木まで多種に及ぶが，今回の調査 では, 植栽後 1 年以内という比較的短期間の経過を見ることにな るため, 生育量が大きく, その把握が比較的容易に行えると考え られる地被類と低木類を対象として計測を行った。なお，植栽植 物は全てポット苗もしくはコンテナ苗を用いて列植してあり，植 栽時のダメージは最小限になるように考慮されている。

\section{3. 測定および解析方法}

\section{(1) 測定方法}

地被類，低木類のうち，試験区別の伸長量が比較的容易に，定 量的に把握できると考えられた 6 種（ヒペリカム，セイヨウイワ ナンテン, コウライシバ, 八イビャクシン，アセビ，ヒラドッッ ジ）について, 表一 2 に示すような項目を 1997 年 3 月 7 日に計 測した。なお,コゥライシバ以外の 5 種については枯死株数も計 数した。測定は表一 3 に示す 6 種の基盤区で行った。なお，以下 の図表では表一 3 石端欄に示す略称を用いた。

コウライシバについては, $10 \mathrm{~cm} \times 10 \mathrm{~cm}$ のサン゚ルを堀取ったう えで測定を行った。コウライシバの地上茎長とは地表面の直立茎 の最大高であり，根長とは匍匐茎層から伸びた不定根の最大長を 測ったものである。地上茎重量は匍匐茎層と直立茎の合計の重量 であり, 根重量は不定根の重量である。

各測定值のうち，長さに関するものは現地でメジャーを用いて 計測し, 重さに関するものは, サンプルを洗浄の後, 乾燥状態 (105 ${ }^{\circ} \mathrm{C} て ゙ 24$ 時間乾燥) にして精密科で計量した。

サンプリングは各区において 10 から 15 個体程度を無作為に抽 出して行った。なお，セイヨウイワナンテンの自然土壤区（無貯 水）においては枯損が著しく, 生存していた全 4 株についてのみ データを計測した。

(2) 解析方法

(i ) 枯死率の解析

コウライシバを除く植物 5 種について, 計測した枯死株数と植 栽株数の差加生存株数を求め, 枯死数 /生存数の比をとり, $\chi^{2}$ 検定により比率の差を検定し，5\%水準以上で有意なものを 枯死率に差があるものとみなした。はじめに 6 種の基盤別のデー 夕全てに対して検定を行い, 群間の差が有意となった場合は, 個々 に検定を行い差の有無を調べた。

(ii) 伸長量の解析

各々の測定值に対して $\mathrm{F}$ 検定もしくは Kruskal-Wallis 検定 を行い，試験区ごとの測定值間に差が認められるか否かを調へ， $5 \%$ 水準以上で有意な差が認められた場合には, 区ごとの伸長量 の差があると判定し, 多重比較を行い測定值平均間の比率を求め た。一連の解析手順を図一 2 に示す。

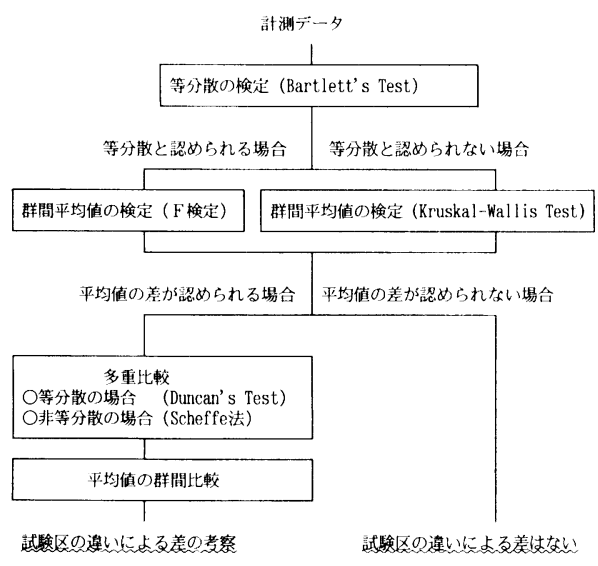

図一２解析手順

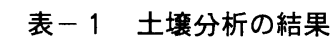

\begin{tabular}{|c|c|c|}
\hline 項目 & 自然土墑 & 人工士壤 \\
\hline 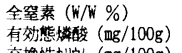 & & $\begin{array}{l}0.37 \\
330\end{array}$ \\
\hline 交換性加帅（凅/100g） & 0.18 & 3.02 \\
\hline
\end{tabular}

表-2 調査対象種と測定項目

\begin{tabular}{|c|c|}
\hline 调查对象種 & 測定項目 \\
\hline 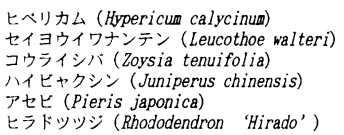 & 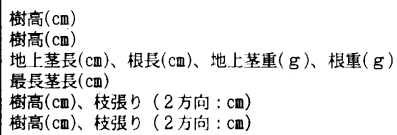 \\
\hline
\end{tabular}

表 -3 計測対象の試験区基盤構造

\begin{tabular}{|c|c|c|c|c|}
\hline No. & 土賟種類 & 館水交 & 貯水曯通叒管 & 略称 \\
\hline 1 & 自然土㲘 & 無 & 無 & 自然 \\
\hline 2 & 自然土裹 & 有 & 無 & 自然貯 \\
\hline 3 & 自然土裹 & 有 & 有 & 自然貯通 \\
\hline 4 & 人工土壤 & 無 & 無 & \\
\hline 5 & 人工土塿 & 有 & 無 & 人工眝 \\
\hline 6 & 人工士猿 & 有 & 有 & 人工館通 \\
\hline
\end{tabular}

\section{4. 解析結果と考察}

\section{(1) 枯死率の差の検定}

各区の枯死率は表－4のようになった。また，植物種ごとの枯 死率の差の検定結果は表－5のようになった。差が認められた 3 種（ヒペリカム, セイヨウイワナンテン, アセビ）については種 ごとに検定を行った。

ヒペリカムでは, 人士上壌区が他の全ての区に対して有意に枯 死率が高かった。自然土壌区と比べると約 4.7 倍, 最も枯死率の 低かった人工士壌の貯水・通気区と比べると 16.0 倍の枯死率と いうことになる。

セイヨウイワナンテンでは最も顕著な差異が見られ, 自然土壌 区での枯死が著しく, 全体の $96 \%$ が枯死していた。最も枯死邦 の低い自然土壌の眝水・通気区と比べると 16.0 倍の枯死率とい うことになる。

アセビについても自然土壤区での枯死が最も多く, 貯水区では 枯死株が無かった。

\begin{tabular}{|c|c|c|c|c|c|c|}
\hline 植物種 & 自然 & 自然眝 & 自然盯通 & 人I & 人工野 & 人工詝通 \\
\hline 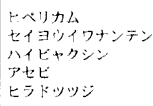 & $\begin{array}{r}7.0(7 / 100) \\
96.0(96 / 100) \\
0.0(0 / 30) \\
23.3(7 / 30) \\
0.0(0 / 30)\end{array}$ & $\begin{array}{r}5.0(5 / 100) \\
10.0(10 / 100) \\
0.0(0 / 30) \\
0.0(0 / 30) \\
0.0(0 / 30)\end{array}$ & $\begin{array}{l}7.0(7 / 100) \\
6.0(6 / 100) \\
0.0(0 / 30) \\
3.3(130) \\
0.0(0 / 30)\end{array}$ & $\begin{array}{r}32.0(32 / 100) \\
46.0(46 / 100) \\
0.0(0 / 30) \\
0.0(0 / 30) \\
0.0(0 / 30)\end{array}$ & $\begin{array}{r}10.0(10 / 100) \\
23.0(23 / 100) \\
0.0(0 / 30) \\
0.0(0 / 30) \\
3.3(1 / 30)\end{array}$ & $\begin{array}{r}2.0(2 / 100) \\
30.0(30 / 100) \\
0.0(0 / 30) \\
10.0(3 / 30) \\
13.3(4 / 30)\end{array}$ \\
\hline
\end{tabular}

\section{表 -5 全区間での植栽植}

\begin{tabular}{|c|c|}
\hline 植物種 & 検定結果 \\
\hline $\begin{array}{l}\text { ヒベリカム } \\
\text { セイヨウイワホンテン } \\
\text { ハイヒヒャクシン } \\
\text { アセビ } \\
\text { ヒラドッツシ }\end{array}$ & $\begin{array}{l}* * \\
* * \\
\mathrm{~ns} \\
* * \\
\mathrm{~ns}\end{array}$ \\
\hline
\end{tabular}

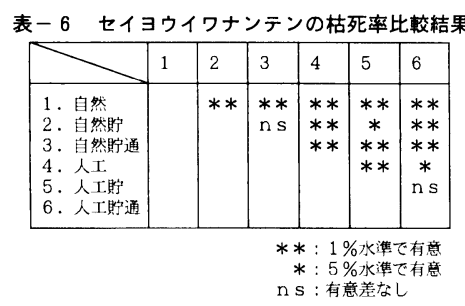

\section{（2）平均値の差の検定}

検定結果を総括して表－７に示す。コウライシバ地上茎長，コ ウライシバ地上茥重量, ヒラドッッジ枝張りの3 項目は Bartlett's Testの結果, 等分散とはみなせないという結論になっ たので, Kruskal-Wallis Test で検定を行った。検定の結果, アセビの樹高，枝張りを除く全ての計測值間で $1 \%$ 水準で有意な 差が認められた。 


\section{（3）多重比較の結果}

(i) ヒペリカム

多重比較の結果を表－ 8 に示す。また，自然土壇区を 1 とした 場合の各区の平均樹高割合を比較したものを図ー 3 に示す。自然 土壌区の樹高は他の全ての区に対して有意に小さな值となった。 全区のうち樹高が最大であったのは，自然土壌の眝水・通気区で ある。

ヒペリカムの生育に対しては，底面眝水，人工土壤の使用とも に有効であると言えよう。

(ii）セイヨウイワナンテン

多重比較および平均樹高割合の比較（図－3）の結果，自然土 壤区よりも自然土壤の貯水区, 人工土壤区, 人工埕の貯水・通 気区で有意に樹高が大きかった。また，人工土壌区と比べて人工 土裹の眝水区は有意に樹高が小さかった。

セイヨウイワナンテンについても自然土壌を使用した区では底 面貯水の有効性が明らかである。しかし，人工土壌の場合，逆に 底面眝水が樹高の増大を抑制する力向に働いているようである。

(iii）コウライシバ

茎長之茥重量の多重比較および平均值割合の比較（図-3）の 結果, 無眝水の人工壌区の地上部の伸長量が有意に大きく，自 然土畩区に比較して茎長で 2.49 倍, 菱重量で 1.77 倍であった。

次に，根長と根重量についても同様に比較を行ったところ，根 長については人工壌区が全ての区に対して有意に大きな值とな り，自然土壌，人工壤いずれの場合も貯水区で無眝水区よりも 有意に小さいという結果になった。根重で見ても概悋同様の傾向 が認められた。

コウライシバでは，人工土壌の無貯水区で顕著な伸長量を示し た。この場合, 底面貯水は地上茥と根の伸長を㧕制する効果を発 揮していると見なせる。現地を観察すると，いずれの区において もコウライシバの生育状況は良好であった。底面眝水を生育のコ ントロールに使用するという手法が使える可能性を示すむのと言 えよう。

(iv）ハイビャクシン

多重比較および平均茥長の比較（図-3）の結果，自然土壤区 よりあ自然十壤の貯水および眝水・通気区，人工土䁃区で有意に 茎長が大きかった。人工壤の貯水区の平均值が最む小さく，こ れも自然土壌区之同様の 3 区に対して有意に小さな值となった。

八イビャクシンについてもセイヨウイワナンテンの場合と同様, 人工土壤区では底面䝪水が茎長の増大を抑制する方向に㗢いてい るようである。

（v）ヒラドッッジ

多重比較および平均樹高の比較（図一 - 4) の結果，平均値最小

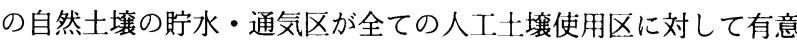
に樹高が小さく，平均值最大の人工土壤の貯水区が全ての自然土 壌使用区に対して有意に樹高が大きいという結果になった。最小 值と最大值を比べると 1.19 倍の差である。

次に，枝張り（被覆面積）についても同様に解析したところ, 人工壌を使用した全ての区が，自然土壌を使用したいずれの区 に対しても有意に枝張りが大きいという結果になった。最小值と 最大值を比べると 1.70 倍の差である。底面眝水および通気の影 響は全く現れていない。図-4であ分かるように，土壌種類の違 いが最も顕著に現れた事例である。

なお，アセビに関しては，試験区ごとの測定值間に $5 \%$ 以上の 水準で有意な差が認められなかったため，多重比較による検討は 行っていない。

ヒラドッッジのような低灌木類は枝張りの伸長量で比較する方 が適切と考えられ，その結果からは，地上部の伸長量に対して底 面貯水の有無はほとんど関係ないが，土壤種類の差は顕著に影響

\section{表 -7 生育量の差の検定結果}

\begin{tabular}{|c|c|c|}
\hline & 険定結果 \\
\hline \multicolumn{2}{|c|}{ ヒベリカム 樹高 } & \\
\hline \multirow{2}{*}{\multicolumn{2}{|c|}{$\begin{array}{l}\text { セイヨウイワナンテン 樹高 } \\
\text { コウシイシバ 地上茥長 }\end{array}$}} & $* *$ \\
\hline & & $* *$ \\
\hline \multirow{2}{*}{\multicolumn{2}{|c|}{ コウライシバ 根長 }} & \\
\hline & & $* *$ \\
\hline & $* *$ \\
\hline & \\
\hline & \\
\hline & & $\mathrm{ns}$ \\
\hline \multicolumn{2}{|c|}{$\begin{array}{l}\text { アセヒ 枝張り（2方们の皘） } \\
\text { 七ラドッシ 樹高 }\end{array}$} & $* *$ \\
\hline
\end{tabular}

表－8 ヒペリカム樹高についての多重比較結果

\begin{tabular}{|c|c|c|c|c|c|c|}
\hline 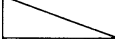 & 1 & 2 & 3 & 4 & 5 & 6 \\
\hline 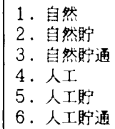 & & $* *$ & $\begin{array}{l}* * \\
\text { ns }\end{array}$ & $\begin{array}{l}* * \\
\text { ns } \\
\text { ns }\end{array}$ & $\begin{array}{l}* * \\
\text { ns } \\
\text { ns } \\
\text { ns }\end{array}$ & $\begin{array}{c}* * \\
* \\
* \\
\text { ns } \\
\text { ns }\end{array}$ \\
\hline
\end{tabular}
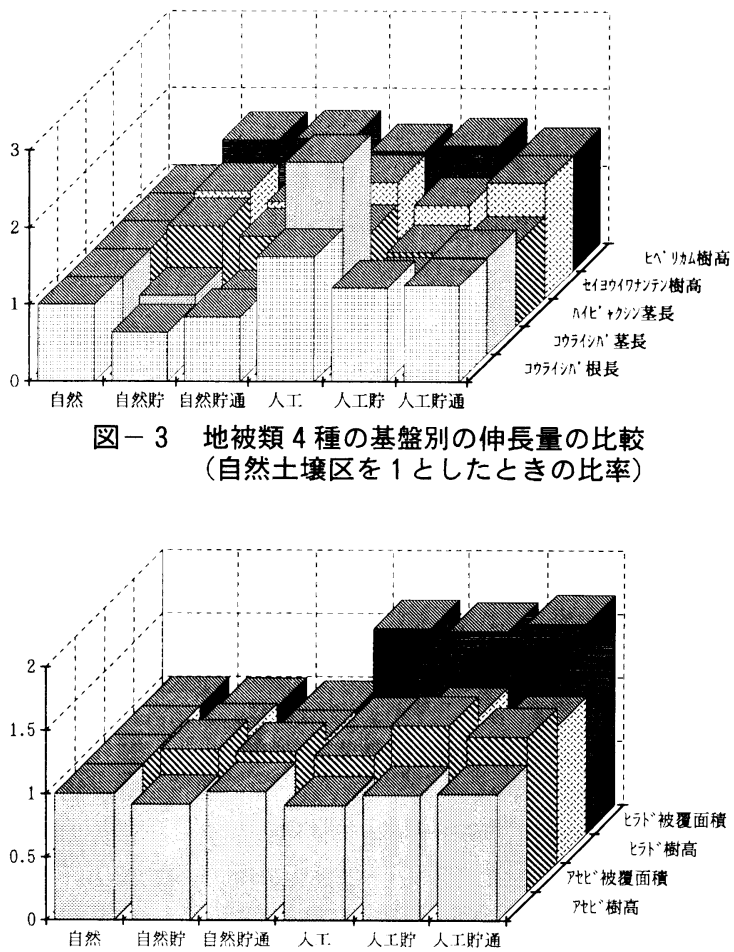

図－4 アセビ，ヒラドッッジの基盤別の伸長量の比較 （自然土壤区を 1 としたときの比率）

するものと判断できる。

\section{(4) 総合考察}

植栽試験区の概要で述べたように，対象とした試験区において は，植え痛み，停滞水による根腐れなどの影響は少ないものと見

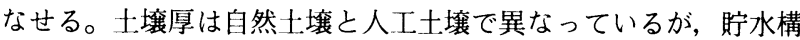
造の違いによる土垣厚の差は無く，貯水構造の差の考察には十分 な解析結果が得られた。土壌種類，底面眝水，底面貯水層への通 気の 3 条件のうち，植栽植物への影響の有無をまとめたものが表一 $9 \sim 10$ である。自然土壌は人工壌と比較して肥料分が非常に 少ないために，人工上壌の方で生育が旺盛となるのでは，という 予想があったが，アセビについては明確な差が見られなかった。 また，枯死率で見た場合も，セイヨウイワナンテン，アセビでは

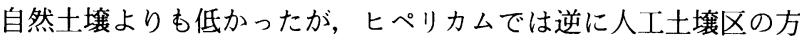


表－9＼cjkstart基盤条件が植栽植物の生存率向上に与える影響

\begin{tabular}{|c|c|c|c|}
\hline 植物種 & 人工土壌の使用 & 底面貯水 & 貯水層への通気 \\
\hline $\begin{array}{l}\text { ヒペリカム } \\
\text { セイヨウイワナンテン } \\
\text { ハイビャクシン } \\
\text { アセビ } \\
\text { ヒラドツッジ }\end{array}$ & $\begin{array}{l}\times \text { (枯死率上昇) } \\
0 \\
\times \\
0 \\
\times\end{array}$ & $\begin{array}{l}\triangle(※ \text { (注 } 1) \\
0 \\
\times \\
\triangle \\
X\end{array}$ & $\begin{array}{l}\Delta(※ \text { 注 } 1) \\
\times \\
\times \\
\times \\
\times\end{array}$ \\
\hline
\end{tabular}

が高めとなった。このように, 全体的な伸長量は人工土壤の方が 大きくなるが, 全ての点で人工壌の方が植物の伸長に関して優 れていると断じることはできなかった。

底面眝水の効果は, 特にセイヨウイワナンテンの生存率向上に 劇的に現れ，ヒペリカム，アセビに対しても枯死率を引き下げる 効果が認められた。今回の測定範囲では, 底面眝水により枯死率 が上昇した例は無く，枯死率の低減には有効な手法と見なしてい いであろう。伸長量について見ると，自然土壌区のヒペリカム， セイヨウイワナンテン, 八イビャクシンで樹高, 茥長の増加効果 が認められた。しかし，人工土壤を使用した区では，セイヨウイ ワナンテン, 八イビャクシンへの効果は樹高, 茎長の抑制として 現れ，自然土裹区の場合と全く逆の結果となった。この伸長抑制 効果はコウライシバでも顕著に見られたが，何故このようになっ たかという理由は現段階では特定できない。今後の研究が必要で ある。

植物を育てるという視点からは，こういった抑制効果というの はマイナスの評価と見なされるが, 積載荷重および維持管理作業 の制限が大きい高架上の緑化というものを考えた場合，これらは 生育コントロールのための一手法として有効であると考えること あできるであろう。

底面眝水層への通気管の設置効果については, 人工土猿区の七 ペリカムについて効果あり（有意水準 $5 \%$ ）とされたが，その他
表一-10 基盤条件が植栽植物の生育量に与える影響

\begin{tabular}{|c|c|c|c|}
\hline 植物種 & 人工十鎄の使用 & 底面貯水 & 貯水層への通気 \\
\hline $\begin{array}{l}\text { ヒペリカム } \\
\text { セイヨウイワナンテン } \\
\text { בウライシバ } \\
\text { ハイビャクシン } \\
\text { アセビ } \\
\text { ヒラドッツジ }\end{array}$ & $\begin{array}{l}0 \\
0 \\
0 \\
0 \\
\times \\
0\end{array}$ & $\begin{array}{l}\bigcirc \\
\triangle(※ \text { 注 } 1) \\
\times(\text { 生育抑制 }) \\
\triangle(※ \text { (※i注 } 1) \\
\times \\
\times\end{array}$ & $\begin{array}{l}x \\
\times \\
\times \\
\times \\
\times \\
\times \\
x\end{array}$ \\
\hline
\end{tabular}

の種については, 枯死率, 伸長量ともに差が見られなかった。こ の結果からは, 底面眝水層へ通気する必要性は小さいということ ができる。

植物種ごとに見た基盤構造の違いに対する反応は様々であり, アセビのように, 基盤構造に全く伸長量が左右されないものもあ れば,コウライシバのように敏感に反応するものもあった。それ ぞれの植物種に対して最適の基盤構造というものが存在するもの と考えられる。

\section{5. おわりに}

今回の調查結果からは, 雨水底面眝水の効果の一端が明確に示 されたが, 植物種や使用する土壌によって, その効果は様々であっ た。高架橋上といった過酷な環境下での生存率向上に大きく寄与 する場合むあれば，ほとんど効果が発揮されない場合ああり，そ の評価は単純には定まらないというのが一つの結論である。植物 種ごとの特性, 土壤種類ごとの特性など, 研究レベルで詰めてい かなければいけない課題が山積しており, 今後の一層の研究・調 查の推進が望まれるところである。

本研究にあたっては, 現地調査において林広一氏の協力を得た。 重量の測定に関しては日本道路（株）技術本部の機器を借用した。 また, 現地調查に関しては建設省奈良国道工事事務所から許可を いただいた。関係諸氏，諸機関に謝意を表して本稿を終える。

\section{引用および参考文献}

1) 建設省奈良国道工事事務所・(財)都市 緑化技術開発機構（1995）：大和高田 $\mathrm{B} \cdot \mathrm{P}$ 高田高架橋橋面緑化基本計画報 告書

2 ）建設省奈良国道工事事務所・(財)都市 緑化技術開発機構（1996）：大和高田 $\mathrm{B} \cdot \mathrm{P}$ 高田高架橋橋面緑化植栽作業報 告書

3 ）興水 肇 (1974): 建築物表層の緑化 : 建築技術 275，141-156
4）輿水 肇 (1977)：人工地盤における 緑地植物の植栽に関する研究: 緑地学 研究 6, 1-140

5 ) 長村智司(1984）：底面灌水に関する研 究 (第 1 報) : 奈良県農業試験場研究 報告 $15,21-27$

6 ) 塚田祥子他 (1997)：薄型システム緑 化装置試験植栽報告 : 第 28 回日本緑 化工学会研究発表要旨集, 57-60

7 ) 筒井 澄(1979): 鉢花の底面給水法 : 農業および園芸 54-4，79-84
8 ）山田宏之他（1996）：高架橋上を使っ た大規模な人工地盤植栽試験について : 日本造園学会関東支部大会研究・発表 要旨 $14,43-44$

9 ) 山田宏之（1997）：(財)都市緑化技術 開発機構における屋上緑化関連研究 : 都市緑化技術臨時增刊号, 28-33

10）(財)都市緑化技術開発機構・特殊緑化 共同研究会 (1996)：新・緑空間デザ イン技術マニュアル：誠文堂新光社

Summary: On the experimental landscape planting field on the overhead line, located in Yamatotakada city in Nara prefecture, the actual conditions of plants were investigated. The results are summarized as follows:

1) An artificial light-weight soil generally encouraged the growth of the plants with the exception of some species.

2) The rain water storing system under the layer of fill-up soil reduced the death rate of the plants.

3) The ventilation pipe for a water storing system was not expected to make obvious effect. 